\title{
Retraction Note: Subject choice in educational data sets by using principal component and procrustes analysis
}

\author{
Ansar Khan ${ }^{1} \cdot$ Mrityunjoy Jana ${ }^{2} \cdot$ Subhankar Bera ${ }^{1} \cdot$ Arosikha Das $^{3}$
}

Published online: 14 June 2018

๑) Springer International Publishing AG, part of Springer Nature 2018

\section{Retraction Note: \\ Model. Earth Syst. Environ. (2016) 2:209 \\ https://doi.org/10.1007/s40808-016-0264-x}

The authors are retracting this article (Khan et al., 2016) because it overlaps with a previously published article (Siswadi et al., 2012). All authors agree with this retraction.

The original article can be found online at https://doi.org/10.1007/ s40808-016-0264-x.

Ansar Khan

khanansargeo@gmail.com

1 Department of Geography and Environment Management, Vidyasagar University, Midnapore, India

2 Department of Education, North Orissa University, Baripada, India

3 Department of Applied Geography, Ravenshaw University, Cuttack, India 